\title{
METHODS FOR RADIO SPECTRUM EVALUATION AND MONITORING
}

\author{
Liljana Gavrilovska, Pero Latkoski, Vladimir Atanasovski \\ Faculty of Electrical Engineering and Information Technologies, \\ "Ss. Cyril and Methodius" University in Skopje, \\ Rugjer Bošković bb, P.O. box 574, 1001 Skopje, Republic of Macedonia \\ liljana@feit.ukim.edu.mk
}

\begin{abstract}
A b s t r a c t: Due to the extensive growth of wireless communications, the usage of radio bands requires a substantial optimized approach and rational treatment. Many new emerged communication scenarios necessitate techniques for optimal spectrum evaluation and monitoring. This paper discusses various such approaches and particularly focuses on spectrum sharing and coexistence presenting several case studies. It offers insights into simulation, modeling and measurement-based methodologies related to spectrum evaluation and utilization, focusing on the effects before and after the digital switchover (DSO) of the TV systems. We investigate the usability of the different propagation models in current wireless systems modeling, including the measurement-based validation of their precision for different scenarios. The article, furthermore, presents laboratory experiments on DVB-T and LTE-800 coexistence. Finally, it discuses a designed example of a nationwide monitoring system for intruder detection, comparing several applied methods and their precision.
\end{abstract}

Key words: radio spectrum; measurement; modeling; LTE; DTV; intruder detection

\section{МЕТОДИ ЗА ЕВАЛУАЦИЈА И МОНИТОРИНГ НА РАДИОСПЕКТАР}

\begin{abstract}
А п с т р а к т: Со развојот на безжичните комуникации се јавува потреба од постојано оптимизирање и рационално користење на опсезите на радиофреквенциите. Многуте нови комуникациски сценарија бараат техники за евалуација и мониторинг на спектарот. Во трудот се разгледуваат повеќе пристапи поврзани со овој проблем со посебен фокус на неколку разработени примери за делење на спектарот и коегзистенција на технологии. Трудот дава детали поврзани со евалуацијата на спектарот преку симулации, моделирање и мерење, фокусирајќи се на ефектите пред и по дигитализацијата на телевизискиот систем. Се испитува користењето на различни пропагациски модели и се прави нивна валидација со мерење. Дополнително се дадени резултати од лабораториски експерименти поврзани со коегзистенција на DVB-T и LTE технологии. На крајот е опишан систем за мониторинг на натрапници во спектарот кој функционира на целата територија на една држава. Испитувани се различни методи за детекција од аспект на нивната прецизност.
\end{abstract}

Клучни зборови: радиоспектар; мерење; моделирање; LTE; DTV; детекција на натрапници

\section{INTRODUCTION}

The continuous increase in data rates and the number of people using mobile communications has been a trend over the last decade. Successful implementation of digital television (DTV) and the emergence of the digital dividend (DD), increases significantly the demand for wireless services, stimulated by new applications and the push towards the Internet of Things (IoT) [1], 5G mobile communications [2] and small cells [3]. The higher number of users, as well as the diversity of the services operating in the same or adjacent bands, contributes to the increased spectrum evaluation and optimization problems. This is why the planning and managing of the spectrum imposes a necessity for international regulations on global, regional and national levels. The global radio services are regulated coherently for all countries worldwide under the auspices of the International Telecommunication Union. The regulation of the spectrum requires clear approaches, rational usage and opti- 
mization, which is not a trivial task and needs some comprehensive research, with variety of applied methodologies. Furthermore, the local regulators need accurate results for the specific problems of spectrum management, caused by the coexistence of wireless technologies. Some examples are: the coexistence of DVB-T and LTE-800 or WiFi-like devices operating within the TV band. Such results can be obtained by focused measurement campaigns, laboratory experiments and comprehensive calculations. Finally, the maintenance and the protection of the spectrum impose a necessity of nationwide monitoring systems.

In this context, the reminder of this article is organized as follows: Section II describes the targeted scenarios; Section III presents several case studies on spectrum evaluation, detailing the results based on modeling and measurements. Section IV contains the laboratory experiments on DVB-T and LTE-800 coexistence. In Section V, the article provides solutions for radio interference and intruder detection on a nationwide operational level and finally, Section VI concludes the article.

\section{USAGE SCENARIOS}

The implementation of DSO leads to TV White Spaces (TVWS), i.e. chunks of available spectrum that can be used for a plethora of applications and services. First and foremost, it is targeted for the mobile broadband services such as LTE-800, as witnessed by the adoption of the DD 1 , as well as the adoption of the DD 2 [4]. However, other potential scenarios are also viable, e.g.:

- Cellular use of white spaces where cellular systems are secondary users of the TV bands and they get access to the available spectrum in addition to the licensed mobile bands.

-WiFi-like usage of TVWS where the secondary system is a fixed network operator, i.e. a WLAN service provider, which deploys opportunistic spectrum access for WLAN-like devices operating in the TV bands.

Both of the envisioned scenarios require a clear and distinct technical and business feasibility study for practical deployment.

\section{DTV SPECTRUM MODELING AND MEASUREMENT}

Multiple interleaved methodologies and approaches should be engaged to obtain relevant results and conclusions regarding the coexistence of different wireless technologies. A full list of utilized methodologies involves: numerical calculations performed by multiple software packages, simulations of behavior prediction, laboratory setup measurements, as well as field measurements. The methodology also includes validation of results, obtained by comparison between the predictions and the measurements. This section provides details in spectrum modeling and measurement. The main focus is on the UHF TV band, pinpointing the most suitable propagation models and measurement setup for DTV spectrum evaluation.

\section{a) Modeling approach}

The process of spectrum modeling for any foreseen spectrum sharing scenario requires usage of (as accurate as possible) radio propagation models. Propagation models in general are divided into empirical-statistical models and physical-analytical models. Empirical models are better adapted to a quick and approximate coverage calculation, while physical-analytical models may be computationally-intensive but they are much more accurate.

In order to verify the relevance of this methodology for assessing TVWS, this section investigates the influence of the used propagation model on the channel availability, taking the territory of the Republic of Macedonia as an example study area [5]. The following figures (Figure 1 and Figure 2) present the number of free TV channels for each location (pixel size $100 \times 100 \mathrm{~m}$ ) within the target territory, when applying two different propagation models. Figure 1 presents the estimated available channels when the calculations include the statistical ITU propagation model [6], without taking into consideration the real geographical terrain in the area. Figure 2 uses the Longley-Rice propagation model [7] and the actual terrain. Both cases apply same regulatory criteria for channels availability.

The figures reveal that due to the highly mountainous geographical characteristics of the target area, the results significantly differ from each other. In particular, the most common number of available channels per location in the first case is one or two, while in the second case this number varies between five and ten. In the first case, the maximum number of free channels is 20 , while in the second case this number is 40 . Obliviously the second approach involving actual terrain plus Longley-Rice propagation model provides more realistic white space availability. 


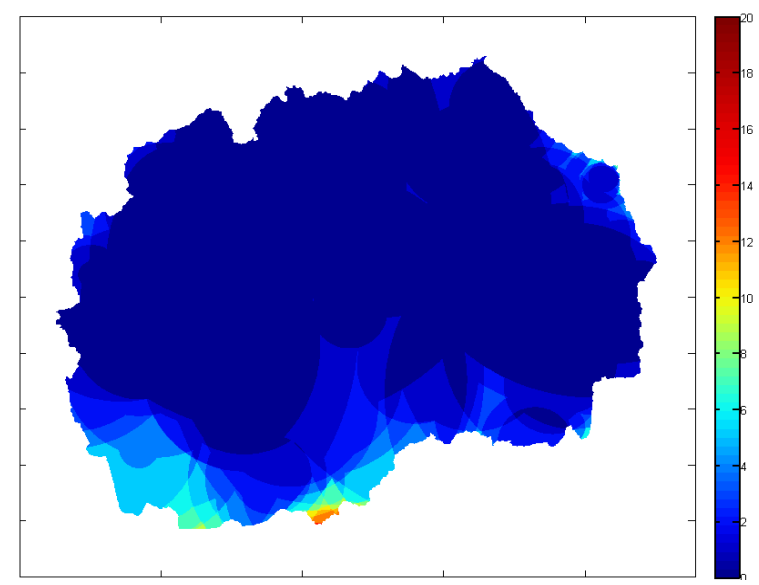

Fig. 1. TV channels availability (ITU propagation model)

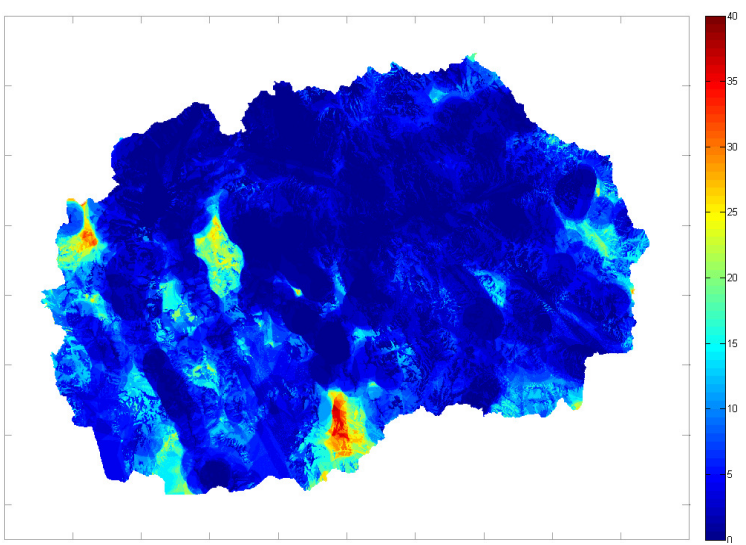

Fig. 2. TV channels availability (Longley-Rice propagation model)

\section{b) Spectrum availability before and after DSO}

The majority of the European countries have completed the process of DSO for their television systems [8]. The major DTV advantages are: increased number of television programs, excellent visual and audio quality, possible mobile and portable reception, plethora of new services and applications on demand, reflection-free picture and constant signal quality.

This sub-section showcases the spectrum availability obtained by measurements, before and after the DSO in Macedonia. Furthermore, the analysis provides an evaluation of the available spectrum usability when assuming WiFi-like secondary users operating in TVWS.

The measurement setup was customized towards an accurate estimation of the TV signals and it involved an Anritsu MS2690A spectrum ana- lyzer and a Sachwarzbeck bi-conical antenna. The results revealed the primary system activities during the DSO transition in terms of frequency spectrum utilization. Figure 3 shows the frequency utilization of the $470-790 \mathrm{MHz}$ band that is foreseen as the main TVWS provider. A visual comparison of the two figures (Fig.3-a and Fig.3-b) proves the expansion of the TVWS after the DSO.

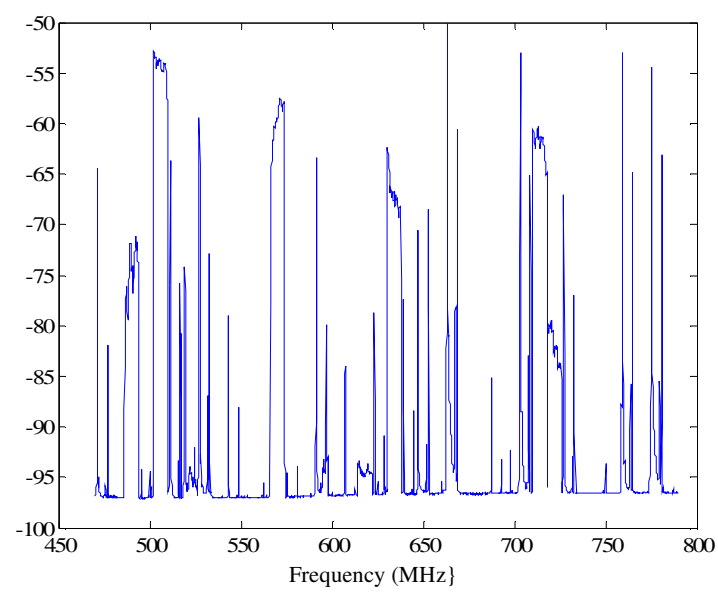

a) before DSO

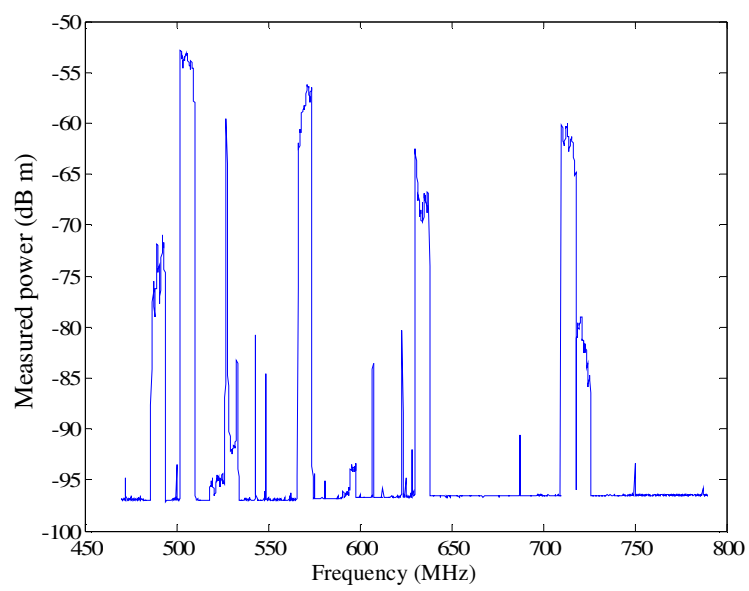

b) after DSO

Fig. 3. Spectrum occupancy in Macedonia

In order to calculate the real usable frequency chunks for secondary communication that will not degrade the operation of the primary TV reception, the analysis firstly needs to determine the maximum received power for each TV channel. These values represent an input to the calculation process, which implements the ECC rules for operation of the White Space Devices (WSD) in the TV band 
based on the SE43 Report 154. According to the SE43, the implementation of any WSD should not violate certain limits related to the degradation of the TV reception location probability. Additionally, the calculation of the secondary spectrum availability needs a precise specification of the WSD transmission power and the required channel bandwidth. One important parameter is the number of adjacent TV channels, which will be protected from the WSD transmissions in terms of the interference produced towards the TV receivers operating on the same channels. The requirement to protect a higher number of adjacent TV channels reduces the secondary spectrum availability.

In terms of TVWS usability, the continuity of the available frequency channels for the WSD operation also represents an important parameter. The blocks of the available channels, also known as available frequency chunks, are multiples of 8$\mathrm{MHz}$ frequency channels. The size of these frequency chunks determines the operational WSD channel bandwidth. According to the results, the most promising scenario in terms of spectrum availability is the one immediately after the DSO, protecting \pm 1 adjacent TV channels, due to the number of available chunks with a size of $8 \mathrm{MHz}$.

A quantitative study on the TVWS availability prior and after the DSO would require a comparison of the secondary system performance in terms of throughput achieved by the WSDs. In order to obtain this performance metric, the calculation process requires an even more detailed description of the secondary system and its capabilities.

The results reveal that the scenario involving the TV band after the DSO, where the secondary system operates over $8 \mathrm{MHz}$ frequency chunks, provides the best performance in terms of achievable throughput. The organization in $16 \mathrm{MHz}$ chunks is less efficient mainly because of the spectrum utilization efficiency. The achievable through iput prior the DSO is much lower for both cases (8 $\mathrm{MHz}$ and $16 \mathrm{MHz}$ ).

\section{LABORATORY EVALUATION OF LTE-800 AND DVB-T COEXISTENCE}

The recent DSO and the release of the upper UHF bands for LTE services, has led to coexistence issues between LTE-800 and DVB-T transmissions. This is a significant problem especially for the DTV service degradation because the DTV receivers are still manufactured to receive signals in the upper UHF bands. Therefore, the regulatory bodies have been particularly active in this area performing tests and deriving the DTV service protection ratios for different types of commercial receivers.

The performed laboratory evaluation predicts the LTE interference on DVB-T system performance. The analysis considers the current regulatory recommendations. It numerically and experimentally derives the DTV protection ratios, comprising an USRP2-based [9] implementation of an LTElike signal generator, a DVB-T transmitter and receiver, and a video encoder. The performance analyses consider different LTE transmission configurations in terms of the transmit/receive power, the bandwidth and the DTV frequency proximity [10].

The LTE-like signal generated with the USRP2 and the WBX daughterboard is combined with a real DVB-T signal (generated with an $R \& S$ transmitter, and video encoded by a Promax H264 encoder) and input directly to a Samsung P2270HD TV. The practical setup and analyses are presented in Figure 4-a). The desired signal levels are achieved using adjustable attenuators and measured using an Anritsu MS2690A signal analyzer. The LTE-like transmission uses a central frequency of $786 \mathrm{MHz}$, while the DVB-T transmission/reception is switched between channels 52-60 to evaluate the adjacent and co-channel DTV protection ratios. The equipment used in the demo setup is listed in the table within Figure 4-b).

Figure 4-c) presents the numerically and experimentally derived protection ratios for the LTElike transmitter and the four different DTV receivers, i.e. three typical Silicon receivers [11] and one Samsung P2270HD TV. The LTE-like transmitter uses $5 \mathrm{MHz}$ bandwidth. The results consider a scenario when the required signal level of the DTV reception is $-50 \mathrm{dBm}$. It is important to notice that the practically obtained (with Samsung P2270HD) and the numerically obtained (with the Silicon receivers from [11]) protection ratios experience increased differences (up to $10 \mathrm{~dB}$ ). This is due to the non-linearity of the signals attenuation caused by the used attenuators and the combiner in the demo. In particular, some frequency chunks of the DVB-T signal are more attenuated than others. Based on the results, the USRP-based LTE-like transmitter is a satisfying LTE emulator, since there are only minor differences in the protection ratios with the results in [11]. 


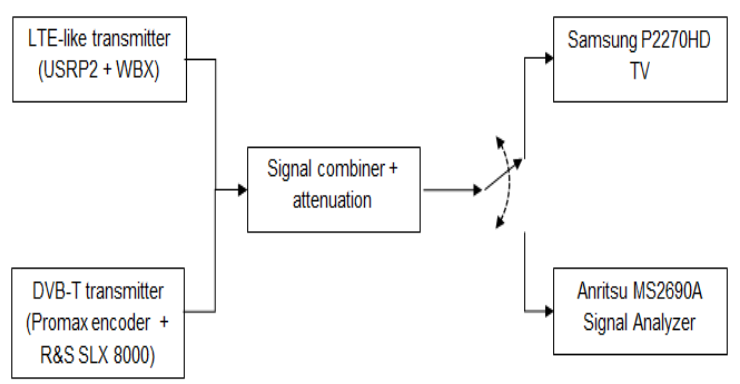

a) Experimental setup

\begin{tabular}{cc}
\hline \hline Equipment & Hardware \\
\hline LTE-like signal generater & USRP2 with WBX daughterboard \\
DVB-T transmitter & Rohde \& Schwarz SLX 8000 low power \\
DVB-T transmitter \\
Video encoder & Promax DVB-H-264 Encoder \\
& and Transcoder \\
DVB-T receiver & Samsung P2270HD TV \\
Signal Analyser & Anritsu MS2690A \\
\hline \hline
\end{tabular}

b) Demo equipment

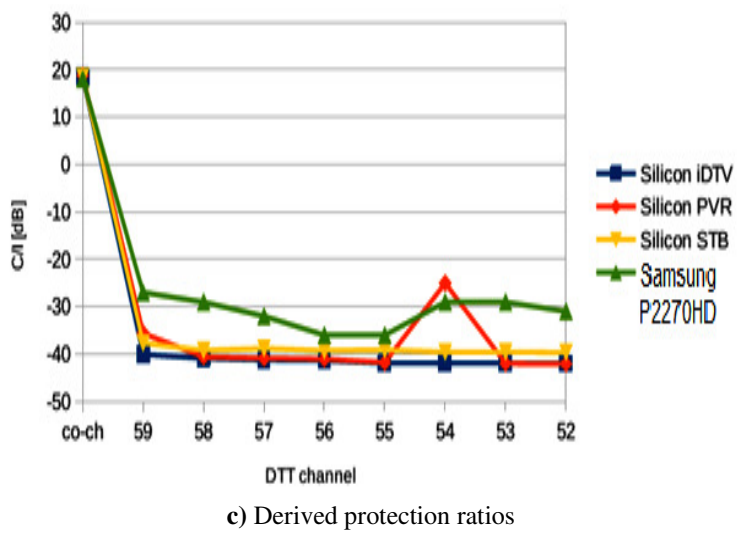

Fig. 4. Demo setup and results for the practical evaluation of DTV protection ratio with the LTE-like transmitter

\section{ANALYSIS OF INTERFERENCE AND INTRUDER DETECTION}

The coexistence of DVB-T and LTE-800 may often lead to undesirable consequences such as interference and service outage. All national regulatory bodies perform radiomonitoring in order to ensure quality reception by the end users. The scope of their work targets continuous radiomonitoring of interference, control of technical and exploitation conditions (usual for operation of licensed wireless transmitters), discovery of unauthorized wireless transmitters as well as monitoring of the spectrum usage.
Modern radiomonitoring encompasses wireless signal receptions by fixed, remote and mobile radiomonitoring stations and sensors. The received signals are then subjected to analysis by Direction Finding (DF), Time Difference of Arrival (TDoA), Angle of Arrival (AoA) and/or hybrid (combination of TDoA and AoA) methods for geolocation of wireless transmitters.

The TDoA method determines the location of a wireless transmitter by using a relative time difference of the received signal by several radiomonitoring stations and sensors. The AoA method determines the direction of arrival of a wireless transmission using a receive antenna array. The hybrid method combines TDoA and AoA characteristics, in order to improve the precision. It exploits parabolic curves and DF lines stemming from the TDoA and AoA methods and analyzes their intersections to precisely find the geolocation of a wireless transmitter [12].

This sub-section focuses on the practical (empirical) evaluation and validation of the TDoA, AoA and hybrid geolocation methods using the nationwide spectrum monitoring system of the Agency of Electronic Communications (AEC) in Macedonia (see Figure 5-a). The empirical results prove the validity and the precision of the designed system and pave the way towards the modern radiomonitoring for effective spectrum usage regulations [13].

The empirical analysis exploits the operational radiomonitoring system of AEC and a fixed wireless transmitter (signal generator Anritsu MS2690A) with a variable output power. The transmitter is used to generate controllable transmissions of different wireless signals (e.g. DVB-T, FM, TETRA, GSM, UMTS) under five distinct measurement scenarios:

1. TDoA geolocation using three sensors closely located to the position of the wireless transmitter.

2. TDoA geolocation using three sensors located far from the position of the wireless transmitter.

3. TDoA geolocation using five sensors.

4. Hybrid geolocation three TDoA sensors (closely located to the actual position of the wireless transmitter) and a DF receiver.

5. Hybrid geolocation three TDoA sensors (located far from the actual position of the wireless transmitter) and a DF receiver 


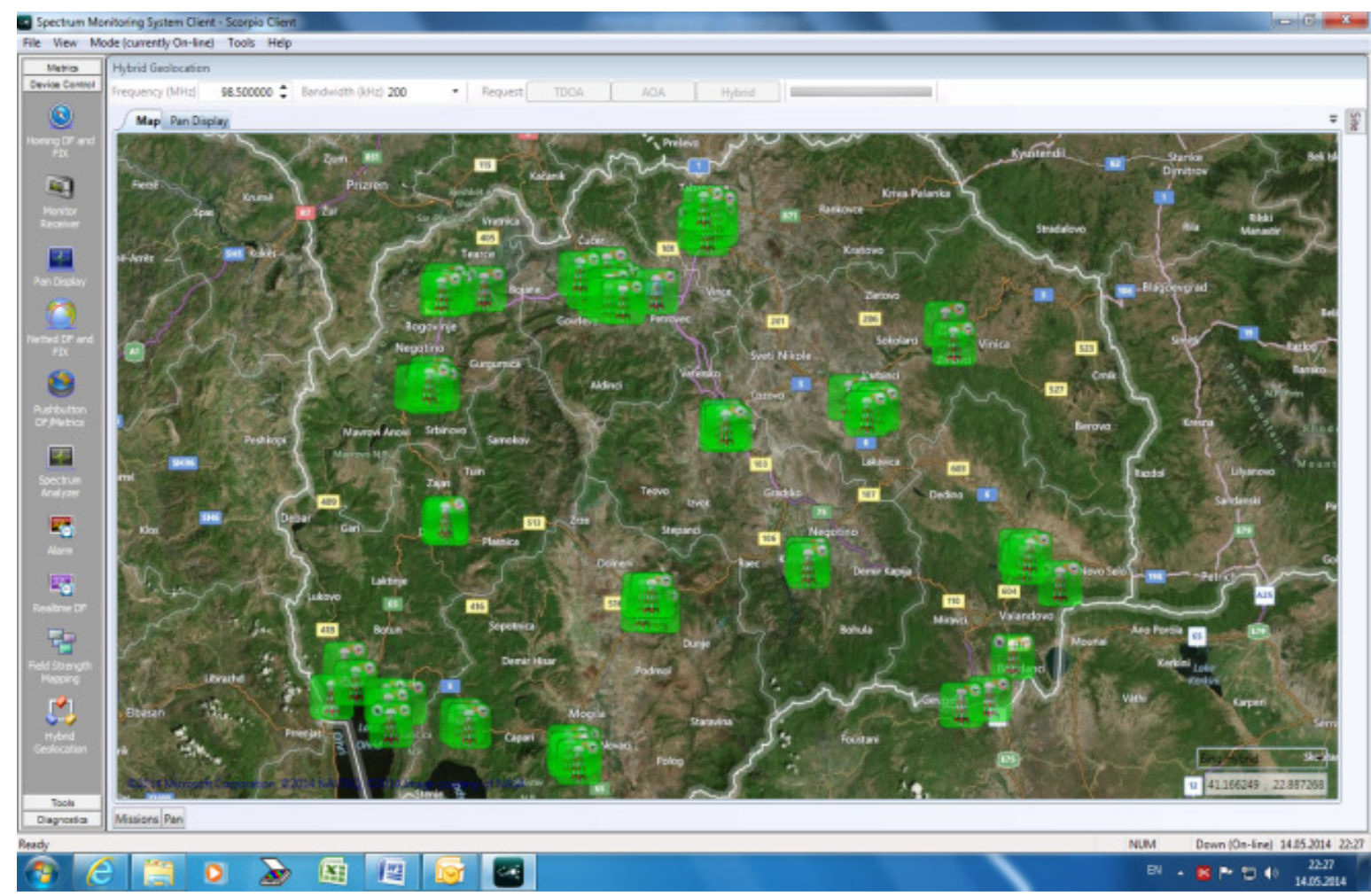

a)

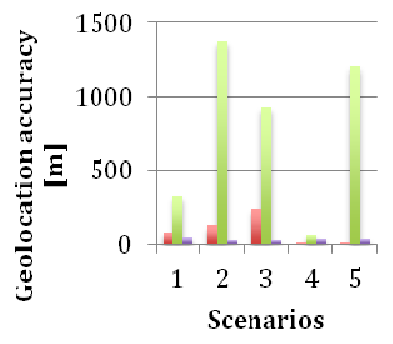

b)

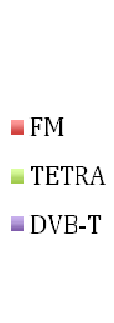

$$
\text { 苞 }
$$

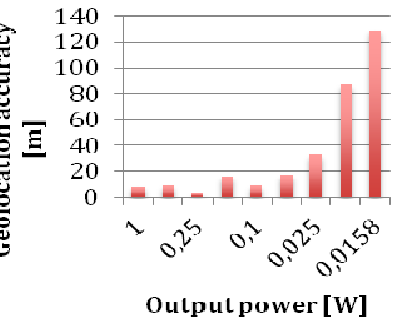

c)

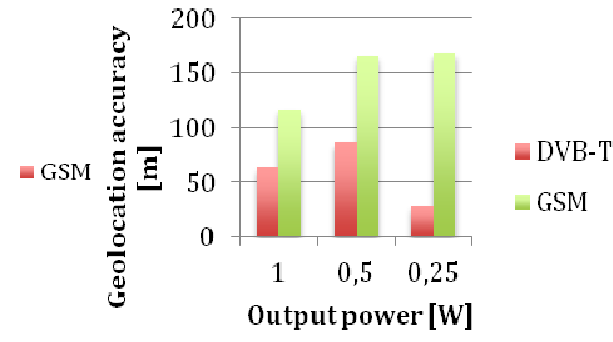

d)

Fig. 5. Transmitter localization using a nationwide monitoring system in the Republic of Macedonia

a) Distribution of TDoA sensors (AEC spectrum monitoring solution); b) Geolocation accuracy of the hybrid method for FM, TETRA and DVB-T signals; c) Geolocation accuracy of the hybrid method for GSM signal with variable output power;

d) Geolocation accuracy of the AoA method for DVB-T and GSM signals with variable output power

The scenarios are chosen to reflect the effect of the geometry and the number of used sensors on the system performance having in mind the actual operational characteristics of the wireless systems. Measurements were conducted with variable output power of the controlled wireless transmitter in order to analyze the minimum transmitter power that can be detected by the system. The metrics of interest is the geolocation accuracy expressed in the coordinate difference between the actual location of the transmitter and the output of the chosen geolocation method.

Figure 5-b shows that the accuracy for the hybrid method is improved when the signal being located has wider bandwidth (DVB-T as opposed to FM and TETRA signals). Figure 5-c shows that the accuracy of the hybrid method is the highest for a GSM signal with lower power (higher powers lead to interferences that affect the accuracy of the system). Finally, Figure 5-d shows that the geolocation for a DVB-T signal does not necessitate TDoA sensors for high accuracy (as opposed to a GSM signal).

The empirical evaluation in this analysis gives a detailed insight into the performance of an operational nationwide radiomonitoring system that incorporates different radiomonitoring stations and different geolocation methods. 
One of the main findings is that the hybrid method offers the best performance in terms of geolocation accuracy. The reason lies in the unique combination of both TDoA and AoA benefits within.

\section{CONCLUSION}

This article discussed a plethora of possible methodologies and approaches in radio spectrum evaluation. These methods (including laboratory and field measurements, numerical and analytical calculations, simulations and modeling) need to be applied in combined manner in order to provide accurate results and mutual validations. The spectrum re-usage and co-existence are hot topics and above all an obvious necessity in the radio-communications today and it requires careful selection of tools and means when estimating the secondary system characteristics. Furthermore, the applied settings of each particular approach must be customized according to the primary and secondary systems. This article elaborated several case studies on spectrum availability, pinpointing to possible issues that may emerge by the coexistence of wireless technologies.

Acknowledgment: The Public Diplomacy Division of NATO in the framework of Science supported this work for Peace through the SfP-984409 Optimization and Rational Use of Wireless Communication Bands (ORCA) project. The authors would like to thank to all partners and participants in the project.

\section{REFERENCES}

[1] P. K. Agyapong, et al.: Design considerations for a 5G network architecture, IEEE Communications Magazine, 52, 11, 65-75 (2014).
[2] Horizon 2020 Advanced 5G Network Infrastructure for Future Internet PPP - Creating a Smart Network that is Flexible, Robust and Cost Effective,http//ec.europa.eu/digital agenda/futurium/en/content/horizon-2020-advanced$5 \mathrm{~g}$-network-infrastructure-future-internet-ppp-creatingsmart-network, accessed, Oct. 2014.

[3] A. Ichkov, V. Atanasovski, L. Gavrilovska: Analysis of Two-Tier LTE Network with Randomized Resource Allocation and Proactive Offloading, Mobile Networks and Applications, 2016, pp. 1-8, DOI: 10.1007/s11036016-0754-0.

[4] ITU World Radiocommunications Conference 2015. http://www.itu.int/en/ITU-R/conferences/wrc/2015/Pages /default.aspx.

[5] P. Latkoski,, J. Karamacoski,, L. Gavrilovska,: Availability assessment of TVWS for Wi-Fi-like secondary system: A case study, $7^{\text {th }}$ International Conference on Cognitive Radio Oriented Wireless Networks - CROWNCOM 2012, Stockholm, Sweden, June 18-20, 2012.

[6] Method for point-to-area predictions for terrestrial services in the frequency range $30 \mathrm{MHz}$ to $3000 \mathrm{MHz}$, International Telecommunications Commission (ITU), Rec. ITU-R P. 1546-3, 2007.

[7] P. Rice, A. Longley, K. Norton, A. Barsis: Transmission Loss Predictions for Tropospheric Communication Circuits, Volume I, National Bureau of Standards, Technical Note, vol. 101, 1967.

[8] Bernard Pauchon: Digital Switch Over Experiences across Europe, ITU International Symposium - Digital Switchover, Geneva, June $17^{\text {th }}, 2015$.

[9] Universal Software Radio Peripheral 2 (USRP2). Information available: http://www.ece.umn.edu/ users/ravi 0022/ class/ee4505/ettus_ds_usrp2_v5.pdf.

[10] D. Denkovski, V. Atanasovski, L. Gavrilovska: Practical evaluation of LTE-800 and DVB-T coexistence, IEEE International Symposium on Broadband Multimedia Systems and Broadcasting (BMSB), Ghent, Belgium, June 17-19, 2015.

[11] OFCOM Technical Report: Technical analysis of interference from mobile network base stations in the $800 \mathrm{MHz}$ band to digital terrestrial television, June, 2011.

[12] A. Grambozov, V. Atanasovski, L. Gavrilovska: Practical evaluation of TDoA, AoA and hybrid methods for geolocation of wireless transmitters, IEEE International Symposium on Broadband Multimedia Systems and Broadcasting (BMSB), Ghent, Belgium, June 17-19, 2015.

[13] http://orca.feit.ukim.edu.mk 
